\title{
The effect of watching political programs on islamic-based party political images among muhammadiyah students
}

\author{
Ahyan Putra ${ }^{\mathrm{a}, 1^{*}}$ Aiur Ochirov ${ }^{\mathrm{b}, 2}$ \\ ${ }^{a}$ UIN Sunan Kalijaga, Jl. Laksda Adisucipto, Papringan, Depok, Sleman, Daerah Istimewa Yogyakarta 5528, Indonesia. \\ ${ }^{\mathrm{b}}$ Buryat State University, Ulitsa Smolina, 24a, Ulan-Ude, Buryatia, 670000, Russia, \\ ${ }^{1}$ ahyanputra76@gmail.com*; ${ }^{2}$ ochirovaur2@mail.ru \\ * corresponding author
}

\section{ARTICLE INFO}

Article history

Received 2020-03-22

Revised 2020-06-04

Accepted 2020-06-04

\section{Keywords}

Watching

Effect

Program

Politic

Images

\section{ABSTRACT}

This study aims to know the effect of watching the Indonesia Lawyers Club political episode program against the image of Islamic-based political parties among the Muhammadiyah Students Association of UIN Sunan Kalijaga ahead of the 2019 Presidential Election. Theories used are Cultivation Theory, television watch intensity, political parties' image, and Islamic based political parties. Validity test uses criteria validity calculated using the Pearson Product Moment formula, while the reliability test uses the Alpha Cronbach formula with the help of SPSS version 15. The type of analysis of this research is quantitative descriptive research with survey methods and data analysis using inferential parametric statistical methods, namely, the Pearson Product analyses Moment with the help of SPSS version 15. Meanwhile, to find out the magnitude of the effect of watching television using the formula Coefficient of Determination. Data collection techniques using questionnaires, interviews, literature studies, and documentation with sampling techniques using random sampling, as many as 62 respondents. From the data processing, it was found that there was an influence between watching the Indonesian Lawyers Club program on political episodes on the image of Islamic-based political parties among the Muhamadiyah Students Association UIN Sunan Kalijaga before the 2019 presidential election. Other variables also influence the formation of the image of political parties. This study uses DK $=60(\mathrm{~N}-2$ or $62-2)$ and the level of probability or significance level of $0.05(5 \%)$, then the table is 0.250 , and from the calculation, the recount is 0.550 . Thus, since counted> tables, Ho is rejected, and Ha is accepted.

This is an open access article under the CC-BY-SA license.

\section{Introduction}

Towards the Presidential Election (Presidential Election) in 2019, political parties began to show their existence in the community. Various methods are used to get support and the right image from the community; one of them is by using mass media [1]. Not surprisingly, many political parties distribute political advertisements for imaging purposes. This imaging is expected to be able to contribute to the vote during the election. However, not all of these images have a positive image among the people, as seen in Islamic-based political parties, because in the 2014 presidential election, Islamic-based political parties only received less than $10 \%$ of the votes [2]. The use of the term Islamic party has two connotations, namely looking at organizational ideology and sociocultural basis [3]. 
Political parties with Islamic ideology in Indonesia include Masyumi (Indonesian Muslim Syuro Council), NU Party, PSII (Indonesian Islamic Sharia Party), Parmusi, United Nations (Crescent Star Party), PPP (United Development Party), and PKS (Party Prosperous Justice) [4]. While the sociocultural base political party consists of PKB (National Awakening Party) and PPP which has supporters from a community organization (organization) called Nahdhatul 'Ulama (NU), PAN (National Mandate Party) supported by Muhammadiyah mass organizations, the UN is supported by Persis, and the Tarbiyah movement group supports PKS in Urban areas [5].

From these data, the parties that are classified in the Islamic-based category are the UN, PKS, PKB, PPP, and PAN. These parties tend to have a religious image compared to other parties because both are established by Islamic community organizations, namely Muhammadiyah, NU, and Muslim communities in general. In the 2014 presidential election, the image of Islamic-based political parties declined. This is seen from the vote acquisition, namely the United Nations, PKS, PPP respectively gained $1.46 \%, 6.79 \%, 6.53 \%$ whereas PKB and PAN received $9.04 \%, 7.59 \%$ ). This decline is due to the two months before the general election, and the mass media focused on the issue of corruption that ensnared party cadres. Thus, television can change the image of a party in the community (television viewers) [6].

Television reporting has a specific effect on the individuals who watch it. This is because the media have influenced individuals/audiences. The impacts that arise can trigger thoughts that cause changes in the positive or negative image of a party. The image of a political party is essential in building public perception (community) to build the party's existence in an election [7].

Mass media such as television have a considerable influence in influencing society. This television is an intermediary tool (audiovisual media) to deliver communication messages to the public, which aims to get the feedback to be achieved [8]. In this case, the communication message conveyed is a message of political communication to get the right image of an audience that is nothing but the community (the people) [9]. Various influences caused by television include changes in clothing style that follow the idol of the artist, fighting or scenes of contention adopted from soap operas and films [10], as well as expressions contained in soap operas. Besides, television also has a positive impact, among others as a medium of information, education, entertainment and social control [11].

There are two specifications of the audience as television viewers, including light class television viewers, those who watch television less than 4 hours a day, and massive television viewers, ie, those who watch television more than 4 hours a day. Thus, people with heavyweight viewing types will be more easily influenced by television than light class viewers [12].

In Indonesia, television is still the people's favorite media. According to Nielsen's survey, digital and conventional media complement each other. In generation $Z$ (ages 10-19) 97\% consume television, $50 \%$ internet, $33 \%$ radio, $7 \%$ pay television, $4 \%$ print media. Whereas in Millennials (aged 20-34 years) 96\% use television, 58\% use the internet, Generation X (age 35-49 years) $97 \%$ use television, 37\% radio, and 33\% internet. Baby Boomers (aged 50-64 years) 95\% use television, $32 \%$ radio and $9 \%$ internet [13].

Therefore, television is often used as propaganda media, which is a tool to influence people to act the way we want [14]. This propaganda is often used before the election, which is the process of selecting and being elected to occupy certain government positions, which are used as a venue for democracy and are carried out with the principles of Direct, Free, Secret, Honest, and Fair [15]. In this election, the community plays an essential role in making decisions, namely choosing leaders who fit the required criteria [16].

In television, there are various programs, both news programs, and entertainment programs. One of the leading programs ahead of the election is the news program [17]. Not surprisingly, in this election year, many news programs have raised political themes or preached about the development of politics in Indonesia. One television broadcast program that intensely preaches politics about the 2019 presidential election is the Indonesia Lawyers Club (ILC) program on TV One. The program is packaged in the form of talk shows that feature dialogue about legal and criminal matters for 210 minutes or 3.5 hours and is guided by a host named Karni Ilyas. The program was broadcast on Tuesday, at 19.30 WIB. The ILC program won the highest rating on Tuesday, August 142018. 
Among students, the ILC program is quite attractive, especially for those who are concerned and have an interest in the political world, such as students who are included in extra-campus organizations. This can be seen from several extra-campus students (Muhammadiyah Students Association members) who watch the ILC program and discuss these shows each episode. One of the campus movement activist organizations at UIN Sunan Kalijaga is the Muhammadiyah Students Association.

This organization has a background in Muhammadiyah, an Islamic community organization in Indonesia. In addition, the subject selection of the Muhammadiyah Students Association UIN Sunan Kalijaga because researchers have observed and seen the fondness of Muhammadiyah Students Association members in watching the ILC program and so that the research to be carried out is more specific so that researchers only use one extra campus organization, the Muhammadiyah Students Association UIN Sunan Kalijaga.

Therefore, researchers chose the Muhammadiyah Students Association UIN Sunan Kalijaga as a research subject and the ILC program as the object of research on "The Effects of Watching the Indonesian Lawyers Club Episode Political Program Against the Image of Islamic-Based Political Parties in Members of the Muhammadiyah Students Association UIN Sunan Kalijaga Towards the 2019 Presidential Election ". Towards the 2019 Presidential Election, what was meant was political episodes that aired in 2018, namely from January to October 2018. This was done to limit the period of program broadcasts.

\section{Theorical Framework}

\subsection{The intensity of Watching Television}

The intensity of watching Television is a person's behavior, which includes the duration of watching, the level of frequency of watching, and the choice of program or motivation to choose the program being watched [18]. While watching Television is an activity using television media. In watching Television, people tend to watch television programs and choose the content of the programs they like - this feeling of love, which then influences a person on the selection of programs to be watched [19].

Everyone has a certain period of watching Television. In one day, some people watch Television with a duration of fewer than 4 hours. However, some watch Television with a duration of more than 4 hours. Of the total duration can be classified into two types or classes of television viewers, namely light-class television viewers, those who watch Television less than 4 hours a day, and heavy-class television viewers, i.e., those who watch television more than 4 hours a day. Thus, people with heavyweight viewing types will be more easily influenced by Television than light class viewers [12].

Also, everyone has a frequency or level of frequency in watching Television, and this level of frequency also tends to indicate the choice of program (motivation to choose the ILC program) that he watches. For example, some people like the x program, so that person will often even tend not to want to miss even one episode of the x program.

There are three things mentioned can be used as a measurement of watching behavior [19], namely:

a. Total watch time (duration) is the amount of time someone spends watching television programs.

b. Frequency of watching (frequency) is the number of times a person watches television programs in a certain period.

c. Program selection (motivation to choose ILC program) the program being watched is the name of the television program being watched (motivation).

The intensity of watching television is related to the exposure of the media to the public. When audiences get media exposure continuously, audiences will get knowledge and the possibility of changing perceptions and attitudes [20]. Media exposure can also be defined as media usage, both the type of media used, the frequency of media use, and the duration of media use [21]. 


\subsection{Image of Political Parties}

Some components can be used in the process of image formation [22], including: (a) Perception, i.e., one's ability to judge an object; (b) Cognition, which is an individual's confidence in the stimulus received; (c) Motive, which is a condition in a person that encourages an individual's desire to carry out certain activities; (d) Attitude, which is the tendency to behave in specific ways.

In the study of political communication, the purpose of political communication is not only to get political support but also to get a political image. Political images can be formed through mass media, social media, and / directly (face to face) of information received by one's five senses. This media is used to convey political messages to others [23]. The political image can be understood as someone's description of politics (power, authority, authority, cooperation, conflict, and consensus) that has meaning, even though it is not always by the actual political reality [24].

The political image in a person can help in the process of understanding, evaluating, and identifying events, ideas or ideas, goals, and political leaders [25]. The image is closely related to political parties and political institutions such as legislative, executive, and judiciary institutions and related to political actors (politicians) [26]. Among these institutions, the one most in need of imaging is political parties because political parties must compete to get the right image from the public, especially in the process of winning an election [27]. A right image arises from public perceptions and impressions about political parties related to the activities of political parties in carrying out their functions and roles [28].

The formation of an excellent political image needs to require consistency from all things done by political parties, including platforms (vision, mission and work programs of political parties), performance, achievements, the reputation of leaders and political cadres, party background, and rhetoric party leader [29]. This is because public responses and judgments are essential elements in research on imagery [30]. Thus the researcher concludes that the image of political parties (in this case Islamic based political parties) can be seen from the perceptions, cognitions, motives, and activist attitudes of the Muhammadiyah Students Association UIN Sunan Kalijaga regarding the activities carried out by Islamic-based political parties.

\section{Method}

This type of research is a quantitative descriptive study with a survey method, which is a quantitative study that uses systematic questions (questionnaires) to respondents, and the data from the questionnaire results are then described and interpreted.

\subsection{Operational Definition}

The operational definition of variables is emphasized on the understanding given by researchers to the variables under study based on existing theories. The operational definitions in this study are:

a. Variable X (Independent), i.e. Watching the Indonesian Lawyers Club (ILC) Program Political Episode is defined as how far the respondent watches the program with an indicator of duration (duration of watching the ILC program), frequency (frequency of watching the ILC program) and program choice (motivation to choose the ILC program) (motivation to watch the ILC program).

b. Variable Y (Dependent), namely the Image of an Islamic-Based Political Party, is defined as the effect obtained from the activities of Muhammadiyah Students Association UIN Sunan Kalijaga activists in consuming (watching) ILC television programs. The indicators are the perceptions, cognitions, motives, and activist attitudes of the Muhammadiyah Students Association UIN Sunan Kalijaga regarding the activities carried out by Islamic-based political parties.

\subsection{Population and Sample}

The population is a generalization area that consists of subjects and research objects determined by the researcher in which there are various populations and characteristics of the subject. His research. The population in this study were activists of Muhammadiyah Students Association UIN Sunan Kalijaga from various faculties. The respondents who became the population in this study 
were respondents with the following criteria: (1) students of UIN Sunan Kalijaga, who became activists of the Muhammadiyah Students Association of UIN Sunan Kalijaga in the year 2018/2019; (2) watch the Indonesia Lawyers Club Program at least seven times.

The number of IMM UIN Sunan Kalijaga Management who served as administrators for the 2018/2019 period were 163 students each one is divided into several faculties, like the table below this:

Table 1. Student Data (member) of Muhammadiyah Students Association UIN Sunan Kalijaga

\begin{tabular}{lc}
\hline \multicolumn{1}{c}{ Faculty } & Amount \\
\hline Faculty of Philosophy & 15 \\
Faculty of Da'wah and Communication & 35 \\
Faculty of Islamic Economics and Business & 27 \\
Faculty of Science and Technology & 14 \\
Faculty of Tarbiyah and Teacher Training & 28 \\
Faculty of Sharia and Law & 11 \\
Faculty of Social Sciences and Humanities & 20 \\
Faculty of Adab and Cultural Sciences & 13 \\
Total & 163 \\
\hline
\end{tabular}

Of the total population, all administrators meet the criteria referred to above. While the sample is part of the number and characteristics of a population. The sampling technique uses the Random Sampling Technique, which is the technique used to determine the random sample. Thus a sample of 62 students was obtained as follows:

Table 2. Sample research

\begin{tabular}{lcc}
\hline \multicolumn{1}{c}{ Faculty } & Population & Sample \\
\hline Faculty of Philosophy & 15 & 6 \\
Faculty of Da'wah and Communication & 35 & 13 \\
Faculty of Islamic Economics and Business & 27 & 10 \\
Faculty of Science and Technology & 14 & 5 \\
Faculty of Tarbiyah and Teacher Education & 28 & 11 \\
Faculty of Sharia and Law & 11 & 4 \\
Faculty of Social Sciences and Humanities & 20 & 8 \\
Faculty of Adab and Cultural Sciences & 13 & 5 \\
Total & 163 & 62 \\
\hline
\end{tabular}

\subsection{Research Instruments}

An instrument is a tool used to measure, observe, or document that can produce quantitative data. The instrument is used to measure the value of the variable under study. The variables studied included the intensity of watching the political episode ILC program (independent variable) and the image of political parties based on Islam (the dependent variable). Therefore we need a data collection tool that is relevant to the focus of the problem. The instrument in this study used a closed questionnaire.

So the task of respondents is only to choose answers from the possibilities that have been determined by researchers. The data collection tool used by researchers is a Likert scale with alternative answers from each variable and given a score as follows: Strongly Agree (SA), Agree (A), Disagree (D), Strongly Disagree (SD). Likert scale is a measurement used to measure the attitudes, opinions, and perceptions of a person or group of people about social phenomena. 
Table 3. Likert Scale

\begin{tabular}{ccc}
\hline Alternative Answer & Score Favorable & Score Unfavorable \\
\hline Strongly Agree & 4 & 1 \\
Agree & 3 & 2 \\
Disagree & 2 & 3 \\
Strongly Disagree & 1 & 4 \\
\hline
\end{tabular}

\subsection{Validity and Reliability}

Validity is the validity or compatibility level of a measuring instrument used to measure something that is being measured. This study uses criteria validity, which is validity that is intended to find out how high the level of similarity of a person's perception with specific criteria, so that it will be more comfortable for researchers to distinguish opinions between individuals. A research instrument is considered valid if the instrument can measure what is being revealed.

Before testing the validity of measuring instruments, first, look for the correlation value between the parts of the measuring instrument as a whole by tolerating each item of measuring instrument with a total score, which is the sum of each item score. To measure the validity of measuring instruments using the Pearson Product Moment formula with the help of the Statistical Application and Service Solutions (SPSS) version 15 application.

Distribution (table $r$ ) for $\alpha=0.05$ and degrees of freedom (DK $=n-2)$ with the decision rule if $r$ count> $r$ table means valid and vice versa if rcount <rtable means invalid. The number of samples used for the validity test was 30 samples by the opinions of Singarimbun and Efendi, who said that the minimum number of questionnaire trials was 30 respondents. With this amount, the distribution of values will be closer to the normal curve. Thus the DK in this study amounted to 28 from the calculation of $\mathrm{DK}=30-2=28$ so that the $\mathrm{r}$ table in the DK was 0.361 .

Then if the instrument is valid, then the criteria for interpretation of the correlation (r) are then seen as follows:

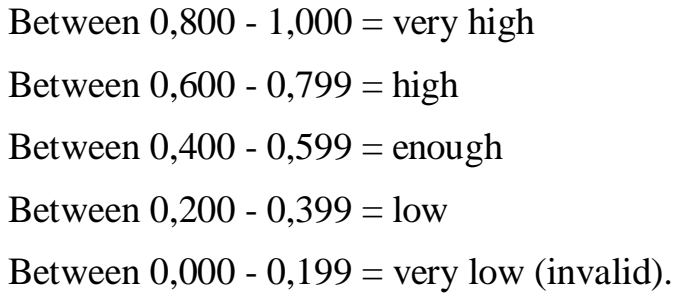

Here are the results of calculating the validity of variable X:

Table 4. The Validity Test Results of the Variable Research Instrument X

\begin{tabular}{ccccc}
\hline \multirow{2}{*}{ Statement Variable $\mathbf{X}$} & $\mathrm{r}$ count & \multirow{2}{*}{ r table 5\% } & \multicolumn{2}{c}{ Information } \\
\cline { 4 - 5 } & & & Validity Test & Interpretation Correlation \\
\hline $\boldsymbol{1}$ & 0.464 & 0.361 & Valid & Enought \\
$\boldsymbol{X} \mathbf{3}$ & 0.369 & 0.361 & Valid & Low \\
$\boldsymbol{X} \mathbf{4}$ & 0.547 & 0.361 & Valid & Enough \\
$\boldsymbol{X 5}$ & 0.429 & 0.361 & Valid & Enough \\
$\boldsymbol{X} \mathbf{6}$ & 0.676 & 0.361 & Valid & High \\
$\boldsymbol{X} \mathbf{7}$ & 0.416 & 0.361 & Valid & Enough \\
$\boldsymbol{X} \boldsymbol{X}$ & 0.427 & 0.361 & Valid & Enough \\
$\boldsymbol{X} \boldsymbol{0}$ & 0.427 & 0.361 & Valid & Enough \\
\hline
\end{tabular}




\begin{tabular}{ccccc}
\hline \multirow{2}{*}{ Statement Variable X } & r count & r table 5\% & \multicolumn{2}{c}{ Information } \\
\cline { 4 - 5 } & & & Validity Test & Interpretation Correlation \\
\hline X10 & 0.551 & 0.361 & Valid & Enough \\
$\boldsymbol{X 1 1}$ & 0.478 & 0.361 & Valid & Enough \\
$\boldsymbol{X 1 2}$ & 0.475 & 0.361 & Valid & Enough \\
$\boldsymbol{X 1 3}$ & 0.375 & 0.361 & Valid & Low \\
$\boldsymbol{X 1 4}$ & 0.380 & 0.361 & Valid & Low \\
$\boldsymbol{X 1 5}$ & 0.411 & 0.361 & Valid & Enough \\
$\boldsymbol{X 1 6}$ & 0.446 & 0.361 & Valid & Enough \\
$\boldsymbol{X 1 7}$ & 0.439 & 0.361 & Valid & Enough \\
$\boldsymbol{X 1 8}$ & 0.373 & 0.361 & Valid & Low \\
Total $\boldsymbol{X}$ & 1 & 0.361 & Valid & Very High \\
\hline
\end{tabular}

Based on the results of the calculation of validity above, it can be concluded that all items of variable $\mathrm{X}$ at the level of significance are 5\% valid. As for the correlation, the majority have enough correlation. While the following are the results of calculating the validity of the $\mathrm{Y}$ variable:

Table 5. Results of Test Validity of Variable Y Research Instruments

\begin{tabular}{|c|c|c|c|c|}
\hline \multirow{2}{*}{$\begin{array}{l}\text { Statement } \\
\text { Y variable }\end{array}$} & \multirow{2}{*}{$\mathbf{R}$ count } & \multirow{2}{*}{$\begin{array}{c}\mathrm{R} \text { table } 5 \% \\
(\mathrm{~N}=30) \mathrm{dk}= \\
30-2=28\end{array}$} & \multicolumn{2}{|c|}{ Information } \\
\hline & & & Validity Test & Interpretation Correlation \\
\hline$Y 19$ & 0.406 & 0.361 & Valid & Enough \\
\hline$Y 20$ & 0.741 & 0.361 & Valid & High \\
\hline$Y 21$ & 0.604 & 0.361 & Valid & High \\
\hline$Y 22$ & 0.475 & 0.361 & Valid & Enough \\
\hline$Y 23$ & 0.538 & 0.361 & Valid & Enough \\
\hline$Y 24$ & 0.555 & 0.361 & Valid & Enough \\
\hline$Y 25$ & 0.793 & 0.361 & Valid & High \\
\hline$Y 26$ & 0.445 & 0.361 & Valid & Enough \\
\hline Y27 & 0.366 & 0.361 & Valid & Low \\
\hline$Y 28$ & 0.774 & 0.361 & Valid & High \\
\hline$Y 29$ & 0.401 & 0.361 & Valid & Enough \\
\hline Y30 & 0.633 & 0.361 & Valid & High \\
\hline$Y 31$ & 0.725 & 0.361 & Valid & High \\
\hline Y32 & 0.622 & 0.361 & Valid & High \\
\hline Y33 & 0.782 & 0.361 & Valid & High \\
\hline$Y 34$ & 0.415 & 0.361 & Valid & Enough \\
\hline Y35 & 0.518 & 0.361 & Valid & Tinggi \\
\hline Y36 & 0.661 & 0.361 & Valid & Tinggi \\
\hline Y37 & 0.445 & 0.361 & Valid & Enough \\
\hline$Y 38$ & 0.812 & 0.361 & Valid & Very High \\
\hline Total Y & 1 & 0.361 & Valid & Very High \\
\hline
\end{tabular}


Based on the results of the calculation of validity above, it can be concluded that all items of variable $\mathrm{Y}$ at the significance level of 5\% are valid. As for the correlation, the majority have a high correlation.

While reliability is the precision or accuracy of a measurement or measuring instrument used. In this study, the reliability test uses the alpha Cronbach formula, which analyzes the reliability of the measuring instrument from one measurement with the help of SPSS version 15. A research instrument is considered reliable if its reliability coefficient ( $\mathrm{r} 11)>0.6 .23$ The following results of the research reliability test:

Table 6. Reliability Test Results

\begin{tabular}{ccc} 
& Cronbach's Alpha & Reliability Statistics \\
\hline Cronbach's Alpha & Based on Standardize & N of points \\
& points & 40 \\
\hline
\end{tabular}

Thus from the above data it can be concluded that this research instrument is reliable because the value of the reliability coefficient is more than $0.6(0.883>0.6)$ and when viewed the reliability interpretation is classified as very high level of reliability because the value ranges from $0.8-1$.

Data analysis is an activity to the group, make a sequence, manipulate, and abbreviate the data so that the data collected is easy to read and understand so that the data can answer the problem and test the research hypothesis. However, before the data collected is analyzed, the data firstly processed through several stages, namely a list of questionnaires (questions/statements) that had been answered by respondents or called documents edited/edited and coded before the results of coding were transferred into worksheets. Then in the worksheet created a table to see the relationship between the phenomena that occur.

Analysis of the data used by researchers is an associative analysis, which is a form of research data analysis to test whether there is a relationship between variables from two or more data groups. While the analysis technique used is the Pearson Product Moment analysis. This technique was chosen because the researcher wanted to see the relationship between variables $\mathrm{X}$ and $\mathrm{Y}$, where the data collected by researchers was in the form of interval data. The relationship that researchers want to look for is the effect of watching the political episode ILC program (X) on the image of an Islamic-based political party (Y) among activists of the Muhammadiyah Students Association UIN Sunan Kalijaga ahead of the 2019 Presidential Election. In its implementation, researchers used computer assistance with the SPSS program ( Statistical Product and Service Solution)

Then to look for how much influence arising from watching the ILC program of political episodes on the image of Islamic-based political parties among activists of the Muhammadiyah Students Association UIN Sunan Kalijaga ahead of the 2019 presidential election using the Coefficient of Determination. With this technique, researchers can predict or estimate how much influence the value of independent variables on the dependent variable. The following formula is the coefficient of determination $(\mathrm{KD}): \mathrm{BC}=(\mathrm{r}) 2 \times 100 \%$

\section{Results and Discussion}

\subsection{Research Data Description}

Researchers will describe the data based on research variables, namely the intensity of watching the Indonesian Lawyers Club (ILC) program on political episodes and the image of Islamic-based political parties. Data processing using Microsoft Excel and SPSS version 15.

Data collected from 62 respondents were classified into three categories, namely low, medium, and high. Determination of categories using the Likert scale guide by determining the minimum value, maximum value, range, mean (M), and standard deviation (SD) of each indicator, which is 
then processed using SPSS version 15. A data is said to fall into categories if: the low category is the total score of each statement indicator in the questionnaire symbolized by $\mathrm{X}$ then $\mathrm{X}<\mathrm{M}-\mathrm{SD}$, medium category (M-SD $<=\mathrm{X}<\mathrm{M}+\mathrm{SD}$ ), and high category $(\mathrm{M}+\mathrm{SD}<=\mathrm{X})$.

While there are four answer choices, namely Strongly Agree (SS), Agree (S), Disagree (TS), and Strongly Disagree (STS), with scores in a sequence of 1, 2, 3, and 4. So that Xmin is obtained from the score lowest, which is 1 times the number of questions per variable indicator, Xmax is obtained from the highest score, which is 4 times the number of questions per variable indicator, range is obtained from Xmax-Xmin, SD is obtained from range divided by 6 (number 6 is the value of determination), and the mean is obtained from Xmaks + Xmin divided by 2 .

\subsection{Intensity to Watch ILC Episode Politics Program}

First is the intensity of watching the political episode ILC program, which includes the duration, frequency, and choice of the program (motivation to choose the ILC program). In the analysis of television viewing intensity data on the audience, it will be categorized that there are two characteristics of the audience based on the intensity of the viewing intensity experienced by the audience (respondents), namely broad audience and light audience. Heavy viewers are those who have high duration and frequency, while light audiences are those who have low duration and frequency. The categorization of a massive audience and light audience will be categorized based on the respondent's viewing behavior which includes, duration, frequency, and program choice (motivation to choose the program) in watching the political episode ILC program.

The number of items in the questionnaire statement is a variable duration indicator. $X$ is 2 . Thus we get Xmin: $1 \times 2=2$, Xmax: $4 \times 2=8$, range: $8-2=6, S D=6 / 6=1$, and $M=(8+2) / 2=10 / 2=5$. Thus, the data falls into a category if:

$$
\begin{aligned}
& \text { Low: } X<5-1 \rightarrow X<4 \\
& \text { Medium: } 5-1<=X<5+1 \rightarrow 4<=X<6 \\
& \text { Height: } 5+1<=X \rightarrow 6<=X
\end{aligned}
$$

\begin{tabular}{|c|c|c|c|c|c|}
\hline & & \multirow{2}{*}{ Frequency } & \multirow{2}{*}{ Percent } & \multirow{2}{*}{$\begin{array}{c}\text { Valid } \\
\text { Percent }\end{array}$} & \multirow{2}{*}{$\begin{array}{c}\text { Cumulative } \\
\text { Percent }\end{array}$} \\
\hline & & & & & \\
\hline \multirow[t]{4}{*}{ Valid } & Low & 4 & 6.5 & 6.5 & 6.5 \\
\hline & Enough & 21 & 33.9 & 33.9 & 40.3 \\
\hline & High & 37 & 59.7 & 59.7 & 100.0 \\
\hline & Total & 62 & 100.0 & 100.0 & \\
\hline
\end{tabular}

Table 7. Duration of Intensity Watch Political ILC Program

Based on the table data above, it can be seen that the significance value is smaller than 0.05 $(0,000<0.05)$ and the correlation value is 0.550 (it belongs to the moderate correlation category because the range of values is 0.41 to 0.60 ). Thus the null hypothesis is rejected and the alternative hypothesis is accepted, meaning that there is an Influence Between the Intensity of Watching the Indonesian Lawyers Club Political Episode Program Against the Image of an Islamic-Based Political Party among Muhammadiyah students ahead of the 2019 presidential election.

In this study, researchers tried to answer the problem formulation that researchers had formulated, namely Is There an Effect of Watching the Indonesia Lawyers Club Political Episode Program Against the Image of Islamic-Based Political Parties among IMM UIN Sunan Kalijaga Students Ahead of the 2019 Presidential Election. Then, the researcher categorized respondent data into in research indicators, namely the indicator variable $\mathrm{X}$ against the variable $\mathrm{Y}$. Indicator $\mathrm{X}$ includes the duration, frequency, and choice of programs (motivation to choose programs) and 
indicator $\mathrm{Y}$ includes perceptions, cognitions, motives, and attitudes where these indicators are used as a measurement of research. From the table data above, it can be seen that the most influential indicator on the image of Islamic-based political parties is the program selection indicator (the audience's motivation to choose the program). This is because program choice indicators often get high total scores compared to duration and frequency indicators. Thus, respondents watch and choose the political episode ILC program because they like, are interested and get the benefits so that the intensity of watching is high.

Second, researchers conducted data analysis using Product Moment assisted by SPSS version 15 (see table 23). The results of the data analysis show that there is an influence between the intensity of watching the Indonesian Lawyers Club Program on Political Episodes on the Image of IslamicBased Political Parties among IMM UIN Sunan Kalijaga Students Ahead of the 2019 Presidential Election, which is seen from the significance value of less than $0.05(0,000<0.05)$ and the correlation value is 0.550 (included in the medium correlation category because the range of values is $0.41-0.60)$. Thus the null hypothesis is rejected and the alternative hypothesis is accepted. Third, researchers look for the amount of influence arising from watching the ILC program of political episodes on the image of Islamic-based political parties using the Coefficient of Determination, as follows: $\mathrm{KD}=(\mathrm{r}) 2 \times 100 \%=(0.550) 2 \times 100 \%=0.3025 \times 100 \%=30.25 \%$. Thus the effect of watching the Indonesia Lawyer Club Program in the 2019 presidential election episode among IMM UIN Sunan Kalijaga Students Ahead of the 2019 Presidential Election was 30.25\%, meaning that the effect arising from watching the political episode episode ILC program was low. This shows there are other factors that influence.

These results are consistent with Cultivation Theory which assumes that television has an impact or influence on the audience even though the impact is limited. The higher the level of one's education, the effect is lower, due to the presence of selective information in the process of receiving messages. In addition, IMM UIN Sunan Kalijaga students also have a discussion forum that discusses political issues or issues that are happening in Indonesia so that the respondents in this study have additional information about politics other than the ILC television program media. Furthermore, television has an edge over other electronic media, such as radio and newspapers, namely television displays two aspects including audio and visual aspects. Both of these aspects are factors that can give the audience attention to each impression so that the process of receiving messages is easier. Television viewers will give and get perceptions, cognitions / knowledge, motives, and attitudes so that it becomes a determining factor in shaping the image of an Islamicbased political party.

The existence of different audio-visual aspects results in the emergence of different understandings for each audience. Heavyweight spectators who have a higher viewing intensity will experience a high cultivation process which also means the audience will accept and view reality like reality on television. Vice versa, the lower class light audience experienced the process of cultivation. In addition, television is able to shape how a person thinks and interacts from stimulus in the form of political knowledge / message he receives. This is evidenced by the level of duration and frequency of respondents who showed a high percentage, namely $59.7 \%$ or 37 respondents and $46.8 \%$ or 29 respondents, respectively. The higher the level of attention the respondent carries out, the more likely the respondent receives a stimulus from the media and the greater the response that will be raised. From the duration, frequency, and program selection data table, respondents of this study belong to the heavyweight audience category.

\section{Conclusion}

After conducting in-depth data analysis it can be concluded that there is an influence between watching the Indonesian Lawyers Club program on political episodes on the image of Islamic-based political parties among Muhammadiyah students ahead of the 2019 presidential election. , 05) and the correlation value is 0.550 means $r$ count $>$ rtable where rtabel is 0.250 with $\mathrm{DK}=60(\mathrm{~N}-2$ / 62-2) so that $0.550>0.250$ (falls into the medium correlation category because the range of values is 0.41 0.60 ) and the effect that was caused by $30.25 \%$. 


\section{References}

[1] M. Ulfah and A. Barry, "Indonesia Leader Forum, post-truth and political interests in social media and television," Int. J. Commun. Soc., vol. 1, no. 1, pp. 17-25, 2019, doi: 10.31763/ijcs.v1i1.18.

[2] U. Jandevi, "Communication strategy to improve women's political participation in Indonesia," Int. J. Commun. Soc., vol. 1, no. 2, pp. 68-81, Sep. 2019, doi: 10.31763/ijcs.v1i2.46.

[3] T. Luhuringbudi, M. D. Syamsuddin, and S. A. Hakim, "Activists communication dynamics for mobilization of minority politics in europe," Int. J. Commun. Soc., vol. 1, no. 2, pp. 43-57, Sep. 2019, doi: 10.31763/ijcs.v1i2.50.

[4] C. Fajri and D. Fadillah, "ANALISA KEGAGALAN KOMUNIKASI POLITIK DALAM PILKADA SERENTAK 2015 DI KABUPATEN SLEMAN (STUDI KASUS PDI PERJUANGAN)," Chanel J. Komun., vol. 5, no. 2, 2017.

[5] U. Jandevi, "New media for increasing political participation in Indonesia," Int. J. Commun. Soc., vol. 1, no. 1, pp. 1-8, 2019, doi: 10.31763/ijcs.v1i1.19.

[6] D. Fadillah, "STRATEGI KOMUNIKASI PENINGKATAN PARTISIPASI POLITIK KADER PEREMPUAN PARTAI AMANAT NASIONAL KABUPATEN SLEMAN DALAM PEMILU LEGISLATIF 2014,” Universitas Gadjah Mada, 2014.

[7] D. Fadillah, "KOMUNIKASI POLITIK ANTAR KOALISI PARLEMEN DI DPR RI," CHANNEL $J$. Komun., vol. 5, no. 1, pp. 111-119, Apr. 2017, doi: 10.12928/channel.v5i1.6357.

[8] K. Jaya, "Venezuela's communication dynamics in rejection of humanitarian assistance from United States of America," Int. J. Commun. Soc., vol. 1, no. 1, pp. 26-33, 2019, doi: 10.31763/ijcs.v1i1.5.

[9] D. Fadillah, "HYPER REALITAS SIMULAKRA TAGAR \#2019GANTIPRESIDEN DALAM PEMILIHAN PRESIDEN INDONESIA 2019,” Profetik, vol. 12, no. 2, pp. 249-260, 2019, doi: https://doi.org/10.14421/pjk.v12i2.1669.

[10] M. I. Jati Kusuma, "Messages of parents affection for children in the movie bulan terbelah di langit amerika," Int. J. Commun. Soc., vol. 1, no. 2, pp. 89-96, Sep. 2019, doi: 10.31763/ijcs.vli2.47.

[11] D. Fadillah, L. Zhenglin, and D. Hao, "Social Media and General Elections in Malaysia 2018 and Indonesia 2019,” J. Komun. ISKI, vol. 4, no. 1, pp. 1-8, 2019, doi: 10.25008/jkiski.v4i1.255.

[12] P. Kitley, Television, Nation, and Culture in Indonesia. Athens: Ohio University Press, 2000.

[13] F. F. Lotan, "Making a positive internet through Socmed Agawe Guyub," Int. J. Commun. Soc., vol. 1, no. 1, pp. 9-16, 2019, doi: 10.31763/ijcs.v1i1.22.

[14] Y. Benkler, R. Farris, and H. Roberts, Network Propaganda, vol. 1. Oxford University Press, 2018.

[15] B. A. Patrick and T. A. Thrall, "Beyond Hegemony: Classical Propaganda Theory and Presidential Communication Strategy After the Invasion of Iraq," J. Mass Commun. Soc., vol. 10, no. 1, pp. 95-118, 2007, doi: https://doi.org/10.1080/15205430709337006.

[16] E. O'Callaghan, "Agitation and propaganda," Socialist Worker Review, 2002. [Online]. Available: https://www.marxists.org/archive/hallas/works/1984/09/agitprop.htm.

[17] N. Mambrol, "John Fiske and Television Culture," Literariness, 2018. [Online]. Available: https://literariness.org/2018/07/17/john-fiske-and-television-culture/.

[18] P. Dahlgren, Television and the Public Sphere. Sage Publication, 1995.

[19] S. Iyengar and D. R. Kinder, News that matters: Television and American opinion. Chicago: The University of Chicago Press Books, 2010. 
[20] S. Livingstone and P. Lunt, "Talk on Television: Audience participation and public debate," in The mass media, democracy and the public sphere, London: Routledge, 2013, pp. 9-35.

[21] A. Drozdek, "Media Ethics," in International Encyclopedia of the Social \& Behavioral Sciences: Second Edition, 2015.

[22] K. L. Hacker, PRESIDENTIAL CANDIDATE IMAGES. New York: Littlefield Publishers, 2004.

[23] K. Hallahan, D. Holtzhausen, B. van Ruler, D. Verčič, and K. Sriramesh, "Defining Strategic Communication," Int. J. Strateg. Commun., 2007, doi: 10.1080/15531180701285244.

[24] M. Lane, "Trade Unions' Initiative To Create Alternative Political Force in Indonesia," ISEAS Perspective, 2018.2 [Online]. Available: https://www.iseas.edu.sg/images/pdf/ISEAS_Perspective_2018_44@50.pdf.

[25] D. Fadillah, "DINAMIKA KOMUNIKASI ORGANISASI MUHAMMADIYAH DIY DAN PENCALONAN SENATOR DPD RI DALAM TINJAUAN TEORI KEPRIBADIAN KELOMPOK RAYMOND CATTELL," MEDIAKOM J. Ilmu Komun., vol. 03, no. 01, pp. 1-12, 2019, doi: http://dx.doi.org/10.32528/mdk.v3i1.

[26] S. Banaji, "Young Citizens and New Media: Learning for Democratic Participation, by Peter Dahlgren," J. Inf. Technol. Polit., vol. 5, no. 4, pp. 411-413, 2008, doi: https://doi.org/10.1080/19331680802555002.

[27] D. Fadillah, L. Zhenglin, and D. Hao, "Big Data and the Revolution of Political Campaign in Indonesia," in Proceedings of the 2019 Ahmad Dahlan International Conference Series on Education \& Learning, Social Science \& Humanities (ADICS-ELSSH 2019), 2019, doi: 10.2991/adics-elssh19.2019.19.

[28] M. Lane, "Contending Rhetoric in Indonesia’s Presidential Elections: An Analysis," ISEAS Perspective, 2019. [Online].

Available: https://www.iseas.edu.sg/images/pdf/ISEAS_Perspective_2019_6.pdf?fbclid=IwAR0TRYriHuXA\%0A TpnCgzeDNuGNuq1Yb_-vzVaDxtVYJ2gHg7F_UiALDYxrluY.

[29] D. Chong and J. N. Druckman, "Framing Theory," Annu. Rev. Polit. Sci., vol. 10, pp. 103-126, 2007, doi: https://doi.org/10.1146/annurev.polisci.10.072805.103054.

[30] Ken Newton, "The Transformation of Governance?," in New Media and Politics, Barrie Axford and Richard Huggins, Ed. California: Sage Publication, 2001, p. 151. 